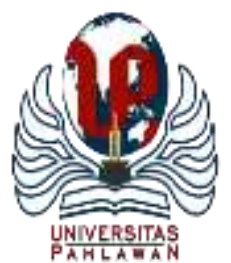

Edukatif : Jurnal Ilmu Pendidikan Volume 3 Nomor 6 Tahun 2021 Halm 3935 - 3945

EDUKATIF: JURNAL ILMU PENDIDIKAN

Research \& Learning in Education

https://edukatif.org/index.php/edukatif/index

\title{
Pengaruh Gaya, Minat, Kebiasaan dan Lingkungan Belajar terhadap Prestasi Belajar Siswa Madrasah Ibtidaiyah di Era New Normal
}

\section{Desy Ana Heryyanti ${ }^{1 凶}$, Ahmad Tanzeh $^{2}$, Prim Masrokan ${ }^{3}$}

IAIN Tulungagung, Indonesia ${ }^{1,2,3}$

E-mail : $\underline{\text { heryyantidesyana@gmail.com }}{ }^{1}, \underline{\text { tanzehmad@gmail.com }}^{2}$, primmasrokanmutohar@gmail.com ${ }^{3}$

\begin{abstract}
Abstrak
Penelitian ini bertujuan untuk mengetahui pengaruh gaya belajar, minat belajar, kebiasaan belajar dan lingkungan belajar terhadap prestasi belajar siswa di era new normal. Penelitian ini menerapkan pendekatan kuantitatif yang berjenis korelasional. Populasi dalam penelitian ini yaitu siswa MI se-kecamatan Bandung Tulungagung dengan jumlah sampel yaitu 94 siswa. Teknik pengambilan data menggunakan angket dan dokumentasi berupa nilai legger siswa sedangkan analisis data yang digunakan yaitu regresi berganda dan regresi sederhana. Hasil penelitian: 1) Gaya belajar memberi pengaruh yang signifikan terhadap prestasi belajar siswa di era new normal. 2) Minat belajar memberi pengaruh yang signifikan terhadap prestasi belajar siswa di era new normal. 3) Kebiasaan belajar memberi pengaruh yang signifikan terhadap prestasi belajar siswa di era new normal. 4) Lingkungan belajar memberi pengaruh yang signifikan terhadap prestasi belajar siswa di era new normal. 5) Gaya belajar, minat belajar, kebiasaan belajar dan lingkungan belajar secara simultan memberi pengaruh terhadap prestasi belajar siswa di era new normal.
\end{abstract}

Kata Kunci: Gaya Belajar, Minat Belajar, Kebiasaan Belajar, Lingkungan Belajar, Prestasi Belajar

\section{Abstract}

This research aims to determine the effect of learning styles, interest in learning, study habits, and learning environment on student achievement in the new normal era. This research applies a correlational quantitative approach. The population in this research was MI students in Bandung Tulungagung sub-district with a total sample of 94 students. The data collection technique used questionnaires and documentation in the form of student legger scores, while the data analysis used was multiple regression and simple regression. The results of this research are: 1) Learning styles have a significant influence on student achievement in the new normal era. 2) Interest in learning has a significant influence on students' achievement in the new normal era. 3) Study habits have a significant influence on student achievement in the new normal era. 4) The learning environment has a significant influence on student achievement in the new normal era. 5) Learning style, learning interest, study habits, and learning environment simultaneously affect student achievement in the new normal era.

Keywords: Learning Style, Learning Interest, Learning Habits, Learning Environment, Learning Achievement

Copyright (c) 2021 Desy Ana Heryyanti, Ahmad Tanzeh, Prim Masrokan

$\triangle$ Corresponding author:

Email : heryyantidesyana@gmail.com

DOI : https://doi.org/10.31004/edukatif.v3i6.1331

ISSN 2656-8063 (Media Cetak)

ISSN 2656-8071 (Media Online)

Edukatif : Jurnal Ilmu Pendidikan Vol 3 No 6 Tahun 2021 p-ISSN 2656-8063 e-ISSN 2656-8071 
3936 Pengaruh Gaya, Minat, Kebiasaan dan Lingkungan Belajar terhadap Prestasi Belajar Siswa Madrasah Ibtidaiyah di Era New Normal - Desy Ana Heryyanti, Ahmad Tanzeh, Prim Masrokan

DOI: https://doi.org/10.31004/edukatif.v3i6.1331

\section{PENDAHULUAN}

Dunia internasional sedang dilanda wabah virus corona. Wabah tersebut melanda di seluruh negara termasuk negara Indonesia. Adanya wabah virus corona di Indonesia sangat mempengaruhi beberapa sektor, salah satunya yaitu sektor pendidikan. Mengingat juga bahwa penularan virus ini sulit untuk diputus karena proses penyebarannya sangat cepat, oleh karena itu untuk mencegah wabah virus meningkat, maka pemerintah menerapkan kebijakan baru terkait tatanan kehidupan baru dimasa pandemi yang dikenal dengan sebutan new normal (Fitriyana, 2020:1). New normal sendiri diartikan sebagai bentuk kebiasaan baru dimana masyarakat diperbolehkan melakukan aktivitas normal seperti sebelum wabah covid terjadi, tetapi diikuti dengan protokol kesehatan untuk mencegah terjadinya penularan virus COVID-19 (Rosidi \& Nurcahyo, 2020:194).

Penerapan pola kehidupan new normal tersebut merubah sistem pembelajaran dari yang awalnya tatap muka kini mengharuskan siswa dan guru menerapkan sistem pembelajaran jarak jauh (PJJ) melalui zoom, google meet, google classroom, maupun whatsapp yang bisa diakses secara online dari luar sekolah yang dimulai dari tingkat sekolah dasar hingga perguruan tinggi (Syaipudin dan Awwalin, 2021:58). Pembelajaran jarak jauh tersebut tentunya memiliki banyak kendala, akan tetapi kegiatan pembelajaran tetap harus berjalan di era new normal ini. Mengingat juga bahwa pendidikan menjadi fondasi untuk kemajuan pembangunan generasi bangsa yang berkualitas, sehingga siswa harus dipersiapkan untuk masa depannya (Rafsanjani, 2020:2). Guru dan orang tua dalam era ini harus bisa membangun kerjasama yang baik, dengan tujuan meningkatkan kualitas belajar siswa untuk meraih keberhasilan belajar di era new normal. Orang tua juga menjadi penghubung antara guru dengan siswa, oleh karena itu baik guru maupun orang tua harus dapat mengetahui faktor yang mempengaruhi keberhasilan belajar yang dilihat dari prestasi belajarnya.

Faktor pertama yang mempengaruhi prestasi belajar yaitu gaya belajar. Menurut Nasution gaya belajar yaitu cara yang relatif tetap yang diterapkan oleh siswa dalam menangkap informasi, cara siswa mengingat, berfikir, serta memecahkan suatu masalah (Cicilia dan Nursalim, 2019:140). Gaya belajar yang dimiliki setiap siswa tidaklah sama. Sesuai dengan pendapat Uno yaitu lain ladang, lain ikannya, lain orang, lain juga gaya belajarnya (Nurdiana dkk, 2021:203). Adanya perbedaan tersebut mengharuskan guru maupun orang tua untuk memahami gaya belajar yang dimiliki siswa. Hal tersebut dimaksudkan supaya siswa dapat dengan mudah menangkap informasi yang diterima. Chatib (2012:100) menyebutkan bahwa tidak ada pelajaran yang sulit dan semua itu sebenarnya hanyalah mitos jika strategi mengajar yang digunakan oleh guru sama dengan gaya belajar siswanya. Sebaliknya jika strategi mengajar yang dilakukan oleh guru berbeda dengan gaya belajar siswa dapat dipastikan bahwa siswa merasa pelajaran tersebut sulit. Pemahaman gaya belajar anak yang dikuasai oleh guru dan orang tua sudah menjadikan merdeka belajar bagi siswa. Gaya belajar tersebut dibagi menjadi tiga yaitu gaya belajar visual, auditori dan kinestetik (Widowati dkk, 2018:275). Gaya belajar visual lebih senang belajar dengan menggunakan indra penglihatan, sehingga kerjasama antara mata dan tangan sangat baik. Gaya belajar auditori lebih senang belajar dengan menggunakan indra pendengaran sehingga siswa mudah memahami informasi dengan baik melalui suara. Siswa dengan gaya belajar kinestetik lebih senang belajar dengan mengutamakan aktivitas fisik (Hasanah dkk, 2018:277-278). Gaya belajar mempengaruhi prestasi belajar siswa dibuktikan dalam penelitiannya Rahmawati (2018:125) dalam tesisnya disimpulkan bahwa gaya belajar mempengaruhi hasil belajar PAI siswa. Subagio (2016:62) dalam tesisnya juga menyimpulkan bahwa gaya belajar dengan prestasi belajar IPA kelas VI MIN 1 kota Malang memiliki hubungan yang signifikan dan positif.

Faktor lain yang mempengaruhi prestasi belajar yaitu minat belajar. Minat belajar adalah dorongan yang menggerakkan seseorang untuk melaksanakan aktivitas belajar yang mana dia dapat dengan bebas memilih apa yang akan dia lakukan tanpa ada tekanan dari orang lain. Minat akan menetap dan meningkat dalam diri seseorang untuk memperoleh dorongan dari lingkungan yang berupa pengalaman. Pengalaman tersebut di dapat berdasarkan interaksi antara individu dengan dunia luar, baik melalui latihan maupun belajar (Sarlin, 
3937 Pengaruh Gaya, Minat, Kebiasaan dan Lingkungan Belajar terhadap Prestasi Belajar Siswa Madrasah Ibtidaiyah di Era New Normal - Desy Ana Heryyanti, Ahmad Tanzeh, Prim Masrokan

DOI: https://doi.org/10.31004/edukatif.v3i6.1331

2018:59). Adanya minat belajar akan membuat siswa lebih mudah memfokuskan perhatiannya ketika belajar, membuat siswa lebih bersemangat dan antusias dalam menemukan pengetahuannya. Siswa tersebut juga tidak mudah putus asa ketika memperoleh tugas yang banyak dan tidak mudah terganggu dengan kondisi yang terjadi di lingkungan sekitar mereka sehingga berdampak pada perolehan prestasi belajarnya (K. P. Rahmawati dkk, 2018:62). Keberadaan minat belajar berpengaruh terhadap prestasi belajar diperkuat oleh penelitian yang dilakukan Humairah (2016:103) dalam tesisnya disimpulkan bahwa minat belajar siswa memberikan pengaruh positif terhadap prestasi belajar IPS siswa di SDN Minasa Upa Kota Makassar.

Faktor lainnya yang berpengaruh yaitu kebiasaan belajar. Kebiasaan yang ada dalam diri siswa dapat mempengaruhi aktivitas belajarnya sehingga akan berdampak pada perolehan prestasi belajar siswa sendiri. Kebiasaan belajar yang baik maupun kurang baik yang tertanam dalam diri siswa harus segera dilatih dan diperhatikan oleh guru maupun orang tua, hal tersebut dimaksudkan supaya siswa bisa merubah kebiasaan yang kurang baik tersebut menjadi kebiasaan yang baik, sehingga siswa akan lebih mudah memilih cara belajar yang baik bagi mereka dan terciptanya situasi belajar yang menyenangkan serta dapat mendukung aktivitas belajar siswa (Ningsih dkk, 2014:82). Kebiasaan belajar mempengaruhi prestasi belajar dibuktikan oleh Istiqomah Risa Wahyuningsih dalam tesisnya disimpulkan bahwa kebiasaan belajar memberikan pengaruh yang signifikan terhadap prestasi belajar serta semakin baik kebiasaan belajarnya maka prestasi yang diperoleh juga semakin baik (Wahyuningsih, 2010:58).

Sedangkan lingkungan belajar menjadi faktor eksternal yang mempengaruhi prestasi belajar. Lingkungan belajar tersebut terdiri dari lingkungan keluarga, lingkungan sekolah dan lingkungan masyarakat yang dikenal dengan tripusat pendidikan. Lingkungan keluarga merupakan lingkungan pertama yang memberikan pengaruh terhadap pembentukan karakter, sikap, dan emosional anak. Lingkungan sekolah membantu siswa supaya mereka mampu mengembangkan potensinya baik yang berkaitan dengan aspek spiritual, moral, emosional, intelektual maupun sosial. Lingkungan masyarakat yaitu lingkungan sosial yang mempunyai norma dan peraturan hidup yang mengikat suatu masyarakat yang harus ditaati baik secara hukum, adat maupun kebiasaan (Johnson dan Mawarni, 2018:20-22). Lingkungan belajar berpengaruh terhadap prestasi belajar siswa dibuktikan oleh Rustiana dan Chalifah (2012:27) yang menyimpulkan bahwa lingkungan belajar terhadap prestasi belajar memiliki pengaruh yang positif dan signifikan.

Berhubungan dengan kegiatan pembelajaran di era new normal maka diperlukan adanya peranan dari pihak keluarga yang penuh dengan rasa pengertian, kasih sayang, dan saling mendukung satu sama lain akan menciptakan lingkungan keluarga yang harmonis dan penuh dengan ketenangan, sehinggaa siswa juga merasa nyaman dan semangat belajar di rumah. Di era new normal ini pengertian dan pendampingan serta cara orang tua dalam mendidik menjadi faktor yang utama dalam menciptakan lingkungan keluarga yang baik sehingga hal tersebut sangat diperlukan oleh siswa guna mendukung kegiatan belajarnya yang mana kegiatan belajar tersebut saat ini lebih banyak dilaksanakan di rumah, tidak hanya itu orang tua juga harus bisa memposisikan diri sebagai guru yang siap membantu kesulitan yang dialami anak ketika belajar, sehingga anak dapat merasakan kenyamanan belajar di rumah.

Hubungan antara pihak sekolah, guru dan siswa serta metode mengajar juga menjadi faktor penentu kesuksesan belajar siswa, sehingga menjaga relasi yang baik antara guru dengan siswa serta selalu membuat inovasi pembelajaran yang menarik juga sangat diperlukan agar pembelajaran menjadi lebih bermakna dan bisa menumbuhkan minat siswa dalam belajar. Sedangkan jika siswa berada dalam lingkungan masyarakat yang dikelilingi oleh orang-orang yang baik dan memiliki jenjang pendidikan yang tinggi dan bergaul dengan teman yang baik maka akan memotivasi siswa untuk lebih giat belajar agar prestasi yang diperoleh juga baik sehingga siswa dapat meneladani masyarakat sekitar. Lingkungan yang ada di sekitar siswa adalah salah satu sumber belajar yang bisa dimaksimalkan untuk mencapai proses dan hasil belajar yang berkualitas bagi siswa sehingga bisa memberikan dampak pada peningkatan prestasi belajar. 
Penelitian ini mengkaji mengenai arti pentingnya faktor internal dan eksternal siswa dalam menunjang keberhasilan pembelajaran yang dilaksanakan di tengah pandemi COVID-19. Hal ini merupakan sebuah fenomena baru yang sebelumnya belum pernah terjadi. Sehingga hal ini penting untuk dilaksanakan bentukbentuk adaptasi. Khususnya sesuai dengan tema penelitian ini yaitu membahas mengenai gaya belajar, minat, kebiasan dan lingkungan belajar sekitar terhadap prestasi belajar. Meskipun masih terdapat banyak faktor yang dapat memberikan pengaruh yang tidak dikaji dalam penelitian ini, tapi khususnya berhubungan dengan konsep adaptasi maka faktor gaya belajar, minat, kebiasaan dan lingkungan belajar sekitar menjadi faktor yang terdekat berkaitan dengan kegiatan belajar.

\section{METODE PENELITIAN}

Penelitian ini menggunakan pendekatan kuantitatif. Penelitian kuantitatif yaitu penelitian yang menekankan penggunaan angka atau kuantitatif yang diangkakan (skoring) untuk penyajian datanya dengan menggunakan statistik (Tanzeh \& Suyitno, 2006:45). Penelitian ini berawal dari adanya teori kemudian dicari permasalahannya dan yang terakhir dianalisis dengan menggunakan statistik, sehingga diperoleh hasil kesimpulannya. Jenis penelitian yang diterapkan dalam penelitian ini yaitu berjenis korelasional. Penelitian korelasional mempelajari tentang hubungan dua variabel atau lebih, yaitu untuk mengetahui sejauh mana variasi dalam satu variabel berhubungan dengan variasi dalam variabel lain (Noor, 2017:40).

Variabel variabel tersebut diantara yaitu variabel bebas (X) yang meliputi gaya belajar, minat belajar, kebiasaan belajar, dan lingkungan belajar sedangkan variabel terikatnya (Y) yaitu prestasi belajar. Populasi dalam penelitian ini yaitu siswa MI se kecamatan Bandung Tulungagung sedangkan lokasi penelitian ini, diambil dari sampel pada beberapa sekolah yaitu MIS Nurul Huda, MIM Plus Suwaru, MIS Al Azhar, dan MI Baitur Rohman (Kecamatan Bandung Tulungagung) yang berjumlah 94 siswa dengan menggunakan teknik sampling cluster sampling . Teknik pengumpulan datanya menggunakan angket dan dokumentasi. Sedangkan analisis data dalam penelitian ini yaitu menggunakan regresi sederhana dan regresi ganda.

\section{HASIL DAN PEMBAHASAN PENELITIAN}

\section{Pengaruh Gaya Belajar Siswa terhadap Prestasi Belajar di Era New Normal}

Hasil analisis dengan bantuan program SPSS menunjukkan bahwa terdapat pengaruh antara gaya belajar terhadap prestasi belajar siswa di era new normal pada MI se-kecamatan Bandung Tulungagung yang dapat dilihat pada tabel berikut.

Tabel 1

Hasil output uji regresi sederhana $X_{1}-Y$

\begin{tabular}{|c|c|c|c|c|c|c|}
\hline \multirow{2}{*}{\multicolumn{2}{|c|}{ Model }} & \multicolumn{2}{|c|}{$\begin{array}{l}\text { Unstandardized } \\
\text { Coefficients }\end{array}$} & \multirow{2}{*}{$\begin{array}{c}\text { Standardized } \\
\text { Coefficients }\end{array}$} & \multirow[t]{2}{*}{$\mathrm{T}$} & \multirow[t]{2}{*}{ Sig. } \\
\hline & & B & Std. Error & & & \\
\hline \multirow{2}{*}{1} & (Constant) & 76.421 & 3.238 & & 23.601 & .000 \\
\hline & Gaya_Belajar & .120 & .037 & .316 & 3.199 & .002 \\
\hline
\end{tabular}

a. Dependent Variable: Prestasi_Belajar

Adanya pengaruh tersebut dapat diketahui pada tabel hasil analisis regresi diatas yang menunjukkan taraf signifikan 5\% lebih besar dari angka signifikasi t gaya belajar yaitu $0,05>0,002$. Selain itu dapat juga

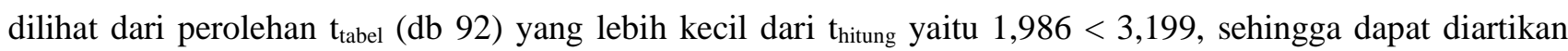
bahwa hipotesis alternatif diterima dan ada pengaruh yang signifikan antara gaya belajar terhadap prestasi belajar siswa di era new normal dengan jumlah sumbangan sebesar 10\% sedangkan sisanya sebesar $90 \%$ dipengaruhi variabel lain. Adapun persamaan regresinya yaitu $\mathrm{Y}=76,421+0,120$.

Hasil penelitian serupa yang bekaitan dengan pengaruh gaya belajar terhadap prestasi belajar dilakukan oleh Setiana (2020:56), dalam jurnalnya disimpulkan bahwa gaya belajar memberi pengaruh terhadap prestasi 
3939 Pengaruh Gaya, Minat, Kebiasaan dan Lingkungan Belajar terhadap Prestasi Belajar Siswa Madrasah Ibtidaiyah di Era New Normal - Desy Ana Heryyanti, Ahmad Tanzeh, Prim Masrokan

DOI: https://doi.org/10.31004/edukatif.v3i6.1331

belajar matematika siswa SMA ITUS Jakarta. Penelitian lain juga dilakukan oleh Sakti dkk (2019: 59) dalam jurnalnya disimpulkan bahwa gaya belajar memberi pengaruh yang signifikan terhadap prestasi belajar siswa pada mata pelajar IPS di SDN 1 Aryojeding. Penelitian serupa lainnya dilakukan oleh Koriaty dan Nurbani (2016:296) dalam jurnalnya disimpulkan bahwa gaya belajar mempengaruhi prestasi belajar mahasiswa pada matakuliah organisasi dan arsitektur komputer IKIP PGRI Pontianak.

Adanya kesesuaian antara gaya belajar dengan kepribadian yang dimiliki seseorang dapat memberikan pencapaian prestasi akademik yang semakin tinggi. Sebaliknya jika tidak ada kesesuaian antara gaya belajar dengan kepribadian maka prestasi akademik yang diperoleh akan semakin rendah. Baik disadari maupun tidak gaya belajar merupakan salah satu kunci untuk mengembangkan kinerja seseorang dalam aktivitas belajar yang mana akan berdampak pada perolehan prestasi belajarnya.

\section{Pengaruh Minat Belajar Siswa terhadap Prestasi Belajar di Era New Normal}

Hasil analisis dengan bantuan program SPSS menunjukkan bahwa terdapat pengaruh yang signifikan antara minat belajar terhadap prestasi belajar siswa di era new normal pada MI se-kecamatan Bandung Tulungagung yang dapat dilihat pada tabel berikut.

\section{Tabel 2}

Hasil output uji regresi sederhana $\mathrm{X}_{2}-\mathrm{Y}$

\begin{tabular}{|c|c|c|c|c|c|c|}
\hline \multicolumn{7}{|c|}{ Coefficients $^{\mathrm{a}}$} \\
\hline \multirow{2}{*}{\multicolumn{2}{|c|}{ Model }} & \multicolumn{2}{|c|}{$\begin{array}{l}\text { Unstandardized } \\
\text { Coefficients }\end{array}$} & \multirow{2}{*}{$\begin{array}{l}\text { Standardized } \\
\text { Coefficients } \\
\text { Beta }\end{array}$} & \multirow[t]{2}{*}{$\mathrm{T}$} & \multirow[t]{2}{*}{ Sig. } \\
\hline & & B & Std. Error & & & \\
\hline \multirow[b]{2}{*}{1} & (Constant) & 76.049 & 3.000 & & 25.348 & .000 \\
\hline & Minat_Belajar & .127 & .036 & .350 & 3.581 & .001 \\
\hline
\end{tabular}

a. Dependent Variable: Prestasi_Belajar

Sesuai dengan tabel hasil analisis regresi diatas dapat diketahui bahwa taraf signifikan 5\% $(0,05)$ lebih besar dari nilai signifikansi t minat belajar yaitu 0,05>0,001 dan nilai tabel (db 92) lebih kecil dari thitung yaitu $1,986<3,581$, sehingga dapat disimpulkan bahwa Ha diterima. Berdasarkan perolehan tersebut menunjukkan bahwa terdapat pengaruh yang signifikan antara minat belajar terhadap prestasi belajar siswa di era new normal. Adapun jumlah sumbangan yang diberikan yaitu sebesar $12,2 \%$ sedangkan sisanya sebesar $87,8 \%$ dipengaruhi variabel lain serta persamaan regresinya yaitu 76,049+0,127.

Penelitian serupa dilakukan oleh Rahman (2019:174), dalam jurnalnya disimpulkan bahwa terdapat pengaruh yang signifikan dan positif antara minat belajar dengan prestasi belajar siswa kelas X SMK se Jakarta Selatan. Penelitian lainnya dilakukan oleh Islamiah (2019:451), dalam jurnalnya disimpulkan bahwa minat belajar memberikan pengaruh yang signifikan dan positif terhadap prestasi belajar matematika di SMKN 1 Cihampelas.

Adanya minat dalam diri siswa akan membuat aktivitas belajar menjadi lebih baik daripada belajar tanpa adanya minat. Pendapat tersebut juga sesuai dengan pendapat Nasution bahwa pelajaran akan terlaksana dengan lancar jika ada minat. Anak yang malas, tidak belajar dan gagal semua itu karena tidak adanya minat (Haswinda dkk, 2018:497).

\section{Pengaruh Kebiasaan Belajar Siswa terhadap Prestasi Belajar di Era New Normal}

Hasil analisis dengan bantuan program SPSS menunjukkan bahwa terdapat pengaruh antara kebiasaan belajar terhadap prestasi belajar siswa di era new normal pada MI se-kecamatan Bandung Tulungagung yang dapat dilihat pada tabel berikut. 
3940 Pengaruh Gaya, Minat, Kebiasaan dan Lingkungan Belajar terhadap Prestasi Belajar Siswa Madrasah Ibtidaiyah di Era New Normal - Desy Ana Heryyanti, Ahmad Tanzeh, Prim Masrokan

DOI: https://doi.org/10.31004/edukatif.v3i6.1331

Tabel 3

Hasil output uji regresi sederhana $X_{3}-Y$

\begin{tabular}{|c|c|c|c|c|c|c|}
\hline \multicolumn{7}{|c|}{ Coefficients $^{\mathrm{a}}$} \\
\hline \multirow{2}{*}{\multicolumn{2}{|c|}{ Model }} & \multicolumn{2}{|c|}{$\begin{array}{l}\text { Unstandardized } \\
\text { Coefficients }\end{array}$} & \multirow{2}{*}{$\begin{array}{c}\text { Standardized } \\
\text { Coefficients }\end{array}$} & \multirow[t]{2}{*}{$\mathrm{T}$} & \multirow[t]{2}{*}{ Sig. } \\
\hline & & B & Std. Error & & & \\
\hline \multirow[b]{2}{*}{1} & (Constant) & 75.124 & 3.948 & & 19.028 & .000 \\
\hline & Kebiasaan_Belajar & .132 & .045 & .294 & 2.948 & .004 \\
\hline
\end{tabular}

a. Dependent Variable: Prestasi_Belajar

Adanya pengaruh tersebut dapat diketahui pada perolehan hasil analsisis regresi diatas yang menunjukkan taraf signifikan 5\% (0,05) lebih besar dari nilai signifikansi t kebiasaan belajar yaitu 0,05 > 0,004. Selain itu dari perolehan $t_{\text {tabel }}$ (db 92) yang lebih kecil dari thitung yaitu 1,986 $<2,948$, dapat diartikan bahwa hipotesis alternatif diterima sehingga terdapat pengaruh yang signifikan antara kebiasaan belajar terhadap prestasi belajar siswa di era new normal. Adapun sumbangan dari kebiasaan belajar yaitu sebesar 8,6\% dan sisanya 91,4\% dipengaruhi oleh variabel lain sedangkan persamaan regresi yaitu $\mathrm{Y}=75,124+0,132$.

Penelitian serupa dilakukan oleh Afrinaval dan Syamwii (2019:632) dalam jurnalnya disimpulkan bahwa ada pengaruh yang signifikan dan positif antara kebiasaan belajar terhadap prestasi belajar siswa. Penelitian lain dilakukan oleh Agustiningsih dan Surjanti (2021:801) dalam jurnalnya disimpulkan bahwa kebiasaan belajar memberikan pengaruh terhadap hasil belajar siswa kelas XI IPS.

Kebiasaan belajar setiap siswa dibedakan menjadi dua yaitu kebiasaan belajar yang baik dan kurang baik. Kebiasaan belajar yang tertata dan direncanakan dengan baik akan mendatangkan dorongan pada diri siswa untuk berprestasi dan memiliki tanggungjawab terhadap tugasnya. Sedangkan kebiasaan yang kurang baik dapat mempersulit siswa dalam memahami dan mendapatkan pengetahuan, sehingga akan menghambat kemajuan belajar siswa dan akan mengakibatkan kegagalan pada siswa dalam menciptakan prestasi yang baik.

\section{Pengaruh Lingkungan Belajar Siswa terhadap Prestasi Belajar di Era New Normal}

Hasil analisis dengan bantuan program SPSS menunjukkan bahwa terdapat pengaruh yang signifikan antara lingkungan belajar terhadap prestasi belajar siswa di era new normal pada MI se-kecamatan Bandung Tulungagung yang dapat dilihat pada tabel berikut.

\section{Tabel 4}

Hasil output uji regresi sederhana $\mathrm{X}_{4}-\mathrm{Y}$

\begin{tabular}{|c|c|c|c|c|c|c|}
\hline \multicolumn{7}{|c|}{ Coefficients $^{\mathbf{a}}$} \\
\hline \multirow{2}{*}{\multicolumn{2}{|c|}{ Model }} & \multicolumn{2}{|c|}{$\begin{array}{l}\text { Unstandardized } \\
\text { Coefficients }\end{array}$} & Standardized & $\mathrm{T}$ & Sig. \\
\hline & & B & Std. Error & Beta & & \\
\hline \multirow{2}{*}{1} & (Constant) & 74.984 & 4.062 & & 18.460 & .000 \\
\hline & Lingkungan_Belajar & .136 & .047 & .289 & 2.900 & .005 \\
\hline
\end{tabular}

Sesuai hasil pengujian diatas diketahui bahwa taraf signifikan $5 \%(0,05)$ lebih besar dari nilai signifikansi t lingkungan belajar yaitu $0,05>0,005$ dan nilai $t_{\text {tabel }}(\mathrm{db}$ 92) yang lebih kecil dari thitung yaitu $1,986<2,900$, maka dapat disimpulkan bahwa Ha diterima. Berdasarkan perolehan tersebut menunjukkan bahwa ada pengaruh yang signifikan antara lingkungan belajar terhadap prestasi belajar siswa di era new normal. Adapun sumbangan yang diberikan yaitu sebesar 8,4\% sedangkan sisanya sebesar $91,6 \%$ dipengaruhi variabel lain serta persamaan regresinya yaitu $\mathrm{Y}=74,984+0,136$.

Penelitian serupa dilakukan oleh Fitriani dkk (2016:10) disimpulkan bahwa terdapat pengaruh yang signifikan antara lingkungan belajar dengan prestasi belajar siswa di SMK Muhammadiyah Pontianak. 
3941 Pengaruh Gaya, Minat, Kebiasaan dan Lingkungan Belajar terhadap Prestasi Belajar Siswa Madrasah Ibtidaiyah di Era New Normal - Desy Ana Heryyanti, Ahmad Tanzeh, Prim Masrokan

DOI: https://doi.org/10.31004/edukatif.v3i6.1331

Penelitian lain dilakukan oleh Ernawati (2021:23) dalam jurnalnya disimpulkan bahwa lingkungan belajar memberikan pengaruh positif terhadap prestasi belajar IPS siswa kelas V SDN 2 Baubau.

Lingkungan belajar yaitu kunci keberhasilan dalam pendidikan yang mana lingkungan belajar dapat mendorong seseorang untuk menjadi baik dan bisa juga merubah seseorang yang awalnya baik menjadi kurang baik. Lingkungan belajar dibedakan menjadi lingkungan keluarga, lingkungan sekolah dan lingkungan masyarakat. Lingkungan keluarga yaitu faktor utama dan awal dalam mendukung kesuksesan anak dalam suatu pendidikan (Kartika, 2021:1319). Lingkungan sekolah merupakan lembaga pendidikan yang penerapannya dalam waktu yang sangat teratur, program yang sangat kaya, dan sistematis, dilakukan oleh tenaga kependidikan yang professional sesuai bidangnya dan dilengkapi dengan fasilitas yang memadai (Martina, 2020:165). Sedangkan lingkungan masyarakat yaitu lingkungan yang dihuni oleh sekelompok manusia yang relatif mandiri, hidup bersama dalam waktu yang cukup lama, dan memiliki kebudayaan yang sama (Rahayu dan Wigna, 2016:7).

\section{Pengaruh Gaya Belajar, Minat Belajar, Kebiasaan Belajar dan Lingkungan Belajar Siswa secara Simultan terhadap Prestasi Belajar di Era New Normal}

Hasil analisis dengan bantuan program SPSS menunjukkan bahwa terdapat pengaruh antara gaya belajar, minat belajar, kebiasaan belajar dan lingkungan belajar secara simultan terhadap prestasi belajar siswa di era new normal pada MI se-kecamatan Bandung Tulungagung yang dapat dilihat pada tabel berikut.

Tabel 5

Hasil output uji regresi berganda

\begin{tabular}{|c|c|c|c|c|c|c|}
\hline \multicolumn{7}{|c|}{ ANOVA $^{a}$} \\
\hline Model & & $\begin{array}{l}\text { Sum of } \\
\text { Squares }\end{array}$ & Df & Mean Square & $\mathrm{F}$ & Sig. \\
\hline \multirow{3}{*}{1} & Regression & 478.647 & 4 & 119.662 & 12.884 & $.000^{\mathrm{b}}$ \\
\hline & Residual & 826.597 & 89 & 9.288 & & \\
\hline & Total & 1305.245 & 93 & & & \\
\hline \multicolumn{7}{|c|}{ a. Dependent Variable: Prestasi_Belajar } \\
\hline $\begin{array}{l}\text { b. Prec } \\
\text { Kebias }\end{array}$ & $\begin{array}{l}\text { ictors: (Cons } \\
\text { aan_Belajar }\end{array}$ & Lingkungan & lajar, $\mathrm{N}$ & Minat_Belajar, & a_Belaj & \\
\hline
\end{tabular}

Adanya pengaruh tersebut dapat dilihat pada hasil analisis regresi berganda yang menunjukkan taraf signifikan $5 \%(0,05)$ lebih besar dari angka signifikansi yaitu $0,05>0,000$. Selain itu dilihat dari perolehan $\mathrm{F}_{\text {tabel }}(\mathrm{df} 4: 90)$ yang lebih kecil dari $\mathrm{F}_{\text {hitung }}$ yaitu $2,47<12,884$, sehingga dapat diartikan bahwa Ha diterima dan ada pengaruh yang signifikan antara gaya belajar, minat belajar, kebiasaan belajar dan lingkungan belajar secara simultan terhadap prestasi belajar siswa di era new normal. Sumbangan yang diberikan oleh keseluruhan variabel bebas terhadap variabel prestasi belajar sebesar 36,7\% sedangkan sisanya 63,3\% dipengaruhi oleh variabel lain. Adapun persamaan regresinya yaitu $\mathrm{Y}=46,086+0,125+0,127+0,109+$ 0,113 .

Hasil penelitian tersebut juga sesuai dengan penelitian yang dilakukan oleh Setiyawan dkk, (2019: 8166), dalam jurnalnya disimpulkan bahwa kebiasaan belajar, minat belajar dan lingkungan belajar secara simultan memberikan pengaruh yang signifikan terhadap prestasi belajar pemograman dasar kelas X TKJ di SMKN 5 Malang. Penelitian selanjutnya dilakukan oleh Yuliana dkk, (2017: 93) dalam jurnalnya disimpulkan bahwa minat dan kebiasaan belajar secara bersama memberikan pengaruh terhadap prestasi belajar statistika lanjut mahasiswa.

Prestasi belajar setiap siswa dipengaruhi oleh dua faktor yaitu faktor internal yang berkaitan dengan sikap dalam belajar, kondisi fisik, intelektual, motivasi dan minat, gaya belajar, serta kebiasaan belajar sedangkan faktor eksternal meliputi lingkungan keluarga, teman sebaya, masyarakat, lingkungan sekolah serta 
3942 Pengaruh Gaya, Minat, Kebiasaan dan Lingkungan Belajar terhadap Prestasi Belajar Siswa Madrasah Ibtidaiyah di Era New Normal - Desy Ana Heryyanti, Ahmad Tanzeh, Prim Masrokan

DOI: https://doi.org/10.31004/edukatif.v3i6.1331

lingkungan yang ada disekitar siswa (Mulyani, 2013:30). Baik faktor internal maupun faktor eksternal masing-masing memberikan pengaruh terhadap prestasi belajar. Hal tersebut telah dibuktikan dalam penelitian ini dan penelitian sebelumnya yang dilakukan oleh Setiyawan dan Yuliana yang menyebutkan bahwa baik gaya belajar, minat belajar, kebiasaan belajar dan lingkungan belajar memberikan pengaruh terhadap prestasi belajar.

Dari beberapa uraian diatas maka diketahui mengenai arti pentinya faktor internal dan eksternal dalam mempengaruhi prestasi belajar di era new normal ini, khususnya yang berkaitan dengan gaya belajar, minat belajar, kebiasaan belajar dan lingkungan belajar, masing-masing menjadi sebuah faktor internal dan eksternal yang penting menjadi suatu perhatian dalam mendorong hasil belajar siswa. Faktor gaya belajar, minat belajar, kebiasaan belajar dan lingkungan belajar menjadi beberapa faktor terdekat yang berkaitan dengan prestasi belajar, karena masing-masing akan memberikan dampak terhadap pola belajar siswa. Hal tersebut penting untuk dilaksanakan dalam membentuk sebuah pola belajar yang kondusif, sehingga kegiatan pembelajaran yang berlangsung dapat berjalan secara maksimal.

Penelitian ini terbatas mengkaji mengenai faktor gaya belajar, minat belajar, kebiasaan belajar dan lingkungan belajar terhadap prestasi belajar. Padahal, masih terdapat banyak faktor ataupun variabel yang berhubungan dengan faktor internal dan eksternal siswa dalam kegiatan belajar. Meski demikian hasil penelitian ini dapat menjadi sebuah pengetahuan baru mengenai pengaruh yang ditimbulkan oleh gaya belajar, minat belajar, kebiasaan belajar dan lingkungan belajar terhadap prestasi belajar siswa di era new normal. Sesuai dengan hasil tersebut maka faktor gaya belajar, minat belajar, kebiasaan belajar dan lingkungan belajar merupakan sebuah faktor penting yang harus mendapat perhatian guna menunjang keberhasilan pembelajaran di masa pandemi COVID-19.

\section{KESIMPULAN}

Sesuai dengan hasil pengujian korelasional yang dilakukan, maka dapat disimpulkan yaitu: 1) Ada pengaruh signifikan gaya belajar terhadap prestasi belajar siswa di era new normal pada MI se-kecamatan Bandung Tulungagung. 2) Ada pengaruh signifikan minat belajar terhadap prestasi belajar siswa di era new normal pada MI se-kecamatan Bandung Tulungagung. 3) Ada pengaruh signifikan kebiasaan belajar terhadap prestasi belajar siswa di era new normal pada MI se-kecamatan Bandung Tulungagung. 4) Ada pengaruh signifikan lingkungan belajar terhadap prestasi belajar siswa di era new normal pada MI se-kecamatan Bandung Tulungagung. 5) Ada pengaruh signifikan gaya belajar, minat belajar, kebiasaan belajar dan lingkungan belajar secara simultan terhadap prestasi belajar siswa di era new normal pada MI se-kecamatan Bandung Tulungagung. Implikasi hasil temuan riset terkait pengaruh gaya belajar, minat belajar, kebiasaan belajar dan lingkungan belajar terhadap prestasi belajar siswa di era new normal pada MI se-kecamatan Bandung Tulungagung dibagi menjadi dua yaitu implikasi teoritis dan implikasi praktis. Hasil riset diatas memberikan pengaruh positif bagi dunia pendidikan. Adanya pengaruh gaya belajar, minat, kebiasaan dan lingkungan belajar yang baik dan kondusif dapat diketahui dari prestasi belajar yang dicapai siswa. Jika siswa memiliki gaya belajar, minat belajar, dan kebiasaan belajar serta berada dalam lingkungan belajar yang baik dan kondusif maka pencapaian prestasi belajar siswa juga akan baik. Guru, orang tua dan pihak sekolah harus dapat bekerjasama dengan baik untuk memberikan dukungan dalam menciptakan lingkungan belajar yang kondusif dan membantu siswa dalam membentuk kebiasaan belajar yang baik serta menciptakan metode pembelajaran yang baik dan lebih bervariasi yang sesuai dengan keberagaman gaya belajar siswa. Hal tersebut dimaksudkan agar siswa merasa nyaman ketika belajar dan mempunyai semangat dalam belajar sehingga minat belajar akan meningkat dan prestasi juga akan meningkat.

\section{DAFTAR PUSTAKA}

Afrinaval, G., \& Syamwil, S. (2019). Pengaruh Kebiasaan Belajar dan Lingkungan Belajar Terhadap Prestasi 
3943 Pengaruh Gaya, Minat, Kebiasaan dan Lingkungan Belajar terhadap Prestasi Belajar Siswa Madrasah Ibtidaiyah di Era New Normal - Desy Ana Heryyanti, Ahmad Tanzeh, Prim Masrokan

DOI: https://doi.org/10.31004/edukatif.v3i6.1331

Belajar Siswa Pada Mata Pelajaran Praktikum Akuntansi Jasa, Dagang Dan Manufaktur Siswa Kelas XI Akuntansi Keuangan Lembaga di SMK Negeri 2 Pariaman Tahun Ajaran 2018/2019. Jurnal Ecogen, 2(4), 624. https://doi.org/10.24036/jmpe.v2i4.7840

Agustiningtyas, P., \& Surjanti, J. (2021). Peranan Teman Sebaya dan Kebiasaan Belajar terhadap Hasil Belajar Melalui Motivasi Belajar di Masa Covid-19. Edukatif: Jurnal Ilmu Pendidikan, 3(3), 794-805.

Ananda, R., Fadhilaturrahmi, F., \& Hanafi, I. (2021). Dampak Pandemi Covid-19 terhadap Pembelajaran Tematik di Sekolah Dasar. Jurnal Basicedu, 5(3), 1689-1694.

Chatib, M. (2012). Orang Tuanya Manusia: Melejitnya Potensi dengan Menghargai Fitrah Setiap Anak. Bandung: PT Mizan Pustaka.

Cicilia, Y., \& Nursalim, N. (2019). Gaya dan Strategi Belajar Bahasa. Edukatif: Jurnal Ilmu Pendidikan, 1(3), 138-149. https://doi.org/10.31004/edukatif.v1i3.30

Ernawati. (2021). Pengaruh Lingkungan Belajar dan Kemandirian Belajar Terhadap Prestasi Belajar IPS Siswa Kelas V SD Negeri 2 Baubau. JPPI Jurnal Penelitian Dan Pendidikan IPS, vol 15(1), 60.

Fadhilaturrahmi, F., Ananda, R., \& Yolanda, S. (2021). Persepsi Guru Sekolah Dasar terhadap Pembelajaran Jarak Jauh di Masa Pandemi Covid 19. Jurnal Basicedu, 5(3), 1683-1688.

Fitriani, D. (2016). Pengaruh Lingkungan dan Sarana Belajar di Rumah terhadap Prestasi Belajar Siswa SMK Muhammadiyah Pontianak. Jurnal Pendidikan Dan Pembelajaran Khatulistiwa, 5(3), 1-11.

Fitriyana, N. (2020). God Spot dan Tatanan New Normal di Tengah Pandemi Covid-19. Human Relations, 3(1), 1-8. https://doi.org/10.1001/jama

Hasanah, I., Kantun, S., \& Djaja, S. (2018). Pengaruh gaya belajar terhadap hasil belajar siswa kelas xi jurusan akuntansi pada kompetensi dasar jurnal khusus di Smk Negeri 1 Jember semester genap tahun ajaran 2017/2018. Jurnal Pendidikan Ekonomi: Jurnal Ilmiah Ilmu Pendidikan, Ilmu Ekonomi, Dan Ilmu Sosial, 12(2), 277-282. https://doi.org/10.19184/jpe.v12i2.8572

Haswinda, H., Sulfasyah, S., \& Akib, T. (2018). Hubungan Antara Minat Belajar Dengan Prestasi Belajar Terhadap Mata Pelajaran Bahasa Indonesia Siswa Kelas IV. JKPD (Jurnal Kajian Pendidikan Dasar), 3(2), 496-507. https://doi.org/10.26618/jkpd.v3i2.1416

Humairah, andi eliyah. (2016). Pengaruh Perhatian Orang Tua dan Minat Belajar terhadap Prestasi Belajar IPS Siswa di SDN Minasa Upa Kota Makassar (Vol. 05).

Islamiah, I. D. (2019). Pengaruh Minat Belajar Siswa Terhadap Prestasi. Juornal On Education, 01(02), 451457.

Johnson, \& Mawarni, S. (2018). Pengaruh Lingkungan Belajar dan Kreativitas Belajar Siswa terhadap Prestasi Belajar Ekonomi Siswa Kelas XI IPS SMA Negeri 1 Tanjung Beringin Kabupaten Serdang Bedagai Tahun Pelajaran 2017/2018. Jurnal Ekonomi Pendidikan Volume, 8(6), 19-33.

Kartika, W. I. (2021). PENDIDIKAN Hubungan antara Lingkungan Keluarga dan Hasil Belajar IPS Siswa di Sekolah Dasar. Edukatif: Jurnal Ilmu Pendidikan Volume 3 Nomor 4 Tahun 2021 Halm 1318 - 1325 EDUKATIF: JURNAL ILMU PENDIDIKAN, 3(4), 1318-1325.

Koriaty, S., \& Nurbani. (2016). Pengaruh Gaya Belajar Dan Motivasi Terhadap Prestasi Belajar Mahasiswa Pada Matakuliah Organisasi Dan Arsitektur Komputer. Jurnal Pendidikan Informatika Dan Sains, 4(2), 287-296.

Martina. (2020). Pengaruh Lingkungan Sekolah Terhadap Hasil Belajar Siswa pada Mata Pelajaran Pendidikan Agama Islam di SMP Negeri 9 Tulung Selapan Kabupaten Oki. Jurnal Kapita Selekta Geografi, 3(2), 47-59.

Mulyani, D. (2013). Hubungan Kesiapan Belajar Siswa Dengan Prestasi Belajar. Konselor, 2(1), $27-31$. https://doi.org/10.24036/0201321729-0-00

Ningsih, Sulistyaningsih, \& Hardjo. (2014). Hubungan Antara Kebiasaan Belajar Dan Dukungan Orangtua 
3944 Pengaruh Gaya, Minat, Kebiasaan dan Lingkungan Belajar terhadap Prestasi Belajar Siswa Madrasah Ibtidaiyah di Era New Normal - Desy Ana Heryyanti, Ahmad Tanzeh, Prim Masrokan

DOI: https://doi.org/10.31004/edukatif.v3i6.1331

Dengan Prestasi Belajar. Analitika: Jurnal Magister Psikologi UMA, 6(2), 77-83.

Noor, J. (2017). Metodologi Penelitian: Skripsi, Tesis, Disertasi, dan Karya Ilmiah. Jakarta: PT Fajar Interpratama Mandiri.

Nurdiana, E., Sarjana, K., Turmuzi, M., \& Subarinah, S. (2021). Kemampuan Menyelesaikan Soal Cerita Matematika Ditinjau Dari Gaya Belajar Siswa Kelas VII. Griya Journal of Mathematics Education and Application, 1(2), 202-211. https://doi.org/10.29303/griya.v1i2.34

Rafsanjani, A. I. (2020). Kebijakan Pendidikan Di Era New Normal. https://doi.org/10.31219/osf.io/29v6a

Rahayu, R. D., \& Wigna, W. (2016). Pengaruh Lingkungan Keluarga, Sekolah dan Masyarakat terhadap Persepsi Gender Mahasiswa Laki-Laki dan Perempuan (Kasus Mahasiswa Sekolah Tinggi Ekonomi Islam TAZKIA Tahun Masuk 2009). Jurnal Penyuluhan, 6(2), 1-23. https://doi.org/10.25015/penyuluhan.v6i2.11451

Rahman, A. N. (2019). Pengaruh Minat Belajar dan Kecerdasan Logik Matematika Siswa terhadap Prestasi Belajar Matematika Siswa Kelas X SMK se Jakarta Selatan. Jurnal Saintika Unpam, 1(2), 166-176.

Rahmawati, D. (2018). Pengaruh Motivasi dan Gaya Belajar Terhadap Hasil Belajar PAI Siswa SMP Negeri 1 Punggur Lampung Tengah. IAIN Metro-Lampung.

Rahmawati, K. P., Djaja, S., \& Suyadi, B. (2018). Pengaruh Minat Belajar Dan Kecerdasan Emosional Terhadap Prestasi Belajar Siswa Kelas Xi Ips Sma Negeri 1 Prajekan Kabupaten Bondowoso Tahun Ajaran 2016/2017. JURNAL PENDIDIKAN EKONOMI: Jurnal Ilmiah Ilmu Pendidikan, Ilmu Ekonomi Dan Ilmu Sosial, 11(2), 61. https://doi.org/10.19184/jpe.v11i2.6448

Rosidi, A., \& Nurcahyo, E. (2020). Penerapan New Normal (Kenormalan). (21), 193-197.

Rustiana, A., \& Chalifah, N. (2012). Pengaruh Lingkungan Belajar dan Kompetensi Profesional Guru Terhadap Prestasi Belajar Siswa SMA N 1 Jekulo Kudus. Jurnal Pendidikan Ekonomi Dinamika Pendidikan, VII(1), 14-28.

Sakti, T. K., Hairunisya, N., \& Sujai, I. S. (2019). Pengaruh Kompetensi Pedagogik Guru dan Gaya Belajar Siswa Terhadap Prestasi Belajar Siswa Pada Mata Pelajaran IPS. Jurnal Pendidikan Ilmu Sosial, 28(1), 53. https://doi.org/10.17509/jpis.v28i1.12818

Sarlin, M. (2018). Analisis Minat Belajar Siswa Terhadap Perubahan Hasil Belajar Ilmu Pengetahuan Sosial di SDN 104 Kota Utara Kota Gorontalo. Cokroaminoto Journal of Primary Education, 1(1), 59.

Setiana. (2020). Pengaruh Gaya Belajar Terhadap Prestasi Belajar Siswa. 1(1), 56.

Setiyawan, R., Rokhmawati, R. I., Wijoyo, S. H., Belajar, K., Belajar, M., Belajar, L., \& Belajar, P. (2019). Analisis Pengaruh Kebiasaan Belajar, Minat Belajar, Lingkungan Belajar Siswa Terhadap Prestasi Belajar Pemrograman Dasar Kelas X Teknik Komputer dan Jaringan ( Studi Kasus : SMKN 5 Malang ). 3(8), 8166-8173.

Subagio, N. H. (2016). Hubungan Gaya Belajar dan Aktivitas Belajar dengan Prestasi Belajar IPA Siswa Kelas VI Madrasah Ibtidaiyah Negeri (MIN) 1 Kota Malang. UIN Maulana Malik Ibrahim Malang.

Syaipudin, L., \& Awwalin, I. N. (2021). The Learning Routines for SD / MI Level in terms of the Impact Covid-19 Pandemic ( Case study at MI Al-Muhajarin Latukan Karanggeneng Lamongan ) Rutinitas Pembelajaran Tingkat SD / MI Ditinjau Dari Dampak Pandemi Covid-19 ( Studi kasus di MI AlMuhajarin . I(I).

Tanzeh, A., \& Suyitno. (2006). Dasar-Dasar Penelitian. Surabaya: Elkaf.

Wahyuningsih, I. R. (2010). Pengaruh metode e-learning dan kebiasaan belajar terhadap prestasi belajar mata kuliah dokumentasi kebidanan.

Widowati, D. A. N., Sutopo, \& Kuswardi, Y. (2018). Eksperimentasi Model Pembelajaran Student Teams Achievement Division (STAD) dengan Strategi QUestion Student Have (QSH) pada Materi Teorema Pythagoras Ditinjau dari Gaya Belajar Siswa Kelas VIII SMP Negeri 16 Surakarta. Jurnal Pendidikan 
3945 Pengaruh Gaya, Minat, Kebiasaan dan Lingkungan Belajar terhadap Prestasi Belajar Siswa Madrasah Ibtidaiyah di Era New Normal - Desy Ana Heryyanti, Ahmad Tanzeh, Prim Masrokan

DOI: https://doi.org/10.31004/edukatif.v3i6.1331

Matematika Dan Matematika (JPMM), II(4), 273-280.

Yuliyani, R., Alamsyah, N., \& Awaludin, A. A. R. (2017). Pengaruh Minat dan Kebiasaan Belajar terhadap Prestasi Belajar Statistika Lanjut Mahasiswa. Jurnal Penelitian Pendidikan Matematika, 1(1), 93. 